Scientia Marina 82(1)

March 2018, 000-000, Barcelona (Spain)

ISSN-L: 0214-8358

doi: https://doi.org/10.3989/scimar.04679.21A

\title{
Age, growth and mortality of Sciaena umbra (Sciaenidae) in the Gulf of Tunis
}

\author{
Inès Chater ${ }^{1}$, Ahlem Romdhani-Dhahri ${ }^{1}$, Jean-Louis Dufour ${ }^{2}$, Kélig Mahé ${ }^{2}$, \\ Nadia Chakroun-Marzouk ${ }^{1}$ \\ ${ }^{1}$ Université de Tunis El Manar, Faculté des Sciences de Tunis, UR11US12 Biologie de la Reproduction et du \\ Développement Animal, 2092 Tunis, Tunisie. \\ (IC) (Corresponding author) E-mail: ineschater13@gmail.com. ORCID iD: https://orcid.org//0000-0002-1059-5015 \\ (AR-D) E-mail: romdhani.ahlem@ gmail.com. ORCID iD: https://orcid.org//0000-0002-1715-7704 \\ (NC-M) E-mail: knn.marzouk@ gnet.tn. ORCID iD: https://orcid.org//0000-0002-9417-8795 \\ ${ }^{2}$ Institut Français de la Recherche pour l'Exploitation de la Mer (IFREMER), Fisheries Laboratory, 150 Quai Gambetta, \\ 62200 Boulogne Sur Mer, France. \\ (J-LD) E-mail: jean.louis.dufour@ifremer.fr. ORCID iD: https://orcid.org/0000-0002-9588-5432 \\ (KM) E-mail: kelig.mahe@ifremer.fr. ORCID iD: https://orcid.org//0000-0002-6506-211X
}

\begin{abstract}
Summary: The growth and mortality of the brown meagre, Sciaena umbra from the Gulf of Tunis, were investigated using a sample of 276 specimens, ranging from 15.3 to $49.2 \mathrm{~cm}$ total length and from 43 to $1565 \mathrm{~g}$ total weight. Specimens were collected from artisanal fisheries between October 2008 and September 2011. Otoliths were extracted, thin cross-sections were realized and radii were measured. The log-linear morphometric relationships between total length-total weight and total length-otolith radius were significant $(\mathrm{p}<0.05)$, showed positive allometry $(b=3.15)$ and isometry $(b=0.90)$, respectively. The marginal analysis suggested that only one growth increment was deposited per year. The maximum age of the brown meagre was 22 years for males and 31 years for females. The fit of the von Bertalanffy growth function was significantly different between sexes $(\mathrm{p}<0.05)$ : $\mathrm{TL}_{\infty}=43.8 \mathrm{~cm}, \mathrm{k}=0.145 \mathrm{y}^{-1}, \mathrm{t}_{0}=-4.88 \mathrm{y}$ for males and $\mathrm{TL}_{\infty}=50.1 \mathrm{~cm}, \mathrm{k}=0.105 \mathrm{y}^{-1}, \mathrm{t}_{0}=-5.71$ y for females. The instantaneous total (Z) and natural (M) mortalities were estimated for each sex, resulting in an exploitation ratio $(\mathrm{E}=\mathrm{F} / \mathrm{Z})$ of 0.43 for males and 0.46 for females.
\end{abstract}

Keywords: brown meagre; thin otoliths; growth; mortality; Gulf of Tunis; Mediterranean Sea.

Edad, crecimiento y mortalidad de Sciaena umbra (Sciaenidae) en el Golfo de Túnez

Resumen: Se investigó el crecimiento y la mortalidad de Sciaena umbra del golfo de Túnez, utilizando una muestra de doscientos setenta y seis especímenes que miden de $15.3 \mathrm{~cm}$ a $49.2 \mathrm{~cm}$ de longitud total y pesan de $43 \mathrm{~g}$ a $1565 \mathrm{~g}$. Las muestras se recogieron de pesquerías artesanales entre octubre de 2008 y septiembre de 2011. Se extrajeron los otolitos, se realizaron secciones transversales delgadas y se midieron los radios. Las relaciones morfométricas logarítmicas entre la longitud total y el peso total de una parte y la longitud total y el radio de otolito de otra parte resultaron significativas $(\mathrm{p}<0.05)$ y mostraron respectivamente alometría positiva $(\mathrm{b}=3.15)$ e isometría $(\mathrm{b}=0.90)$. El análisis marginal sugirió que se depositaba un solo anillo de crecimiento por año. La edad máxima de la corvina negra es de 22 años para los machos y de 31 años para las hembras. El ajuste de la función de crecimiento de von Bertalanffy resultó significativamente diferente entre los sexos $(\mathrm{p}<0.05): \mathrm{TL}_{\infty}=43.8 \mathrm{~cm}, \mathrm{k}=0.145 \mathrm{y}^{-1}, \mathrm{t}_{0}=-4.88$ y para los machos y $\mathrm{TL}_{\infty}=50.1 \mathrm{~cm}, \mathrm{k}=0.105 \mathrm{y}^{-1}, \mathrm{t}_{0}=-5.71$ y para las hembras. La mortalidad instantánea total (Z) y natural (M) se estimó para cada sexo, dando como resultado una tasa de explotación $(\mathrm{E}=\mathrm{F} / \mathrm{Z})$ de 0.43 para los machos y de 0.46 para las hembras.

Palabras clave: corvina negra; otolitos finos; crecimiento; mortalidad; golfo de Túnez; mar Mediterráneo.

Citation/Como citar este artículo: Chater I., Romdhani-Dhahri A., Dufour J.-L., Mahé K., Chakroun-Marzouk N. 2018. Age, growth and mortality of Sciaena umbra (Sciaenidae) in the Gulf of Tunis. Sci. Mar. 82(1): 000-000. doi: https://doi. org/10.3989/scimar.04679.21A

Editor: S. Somarakis.

Received: June 19, 2017. Accepted: December 18, 2017. Published: January 30, 2018.

Copyright: (c) 2018 CSIC. This is an open-access article distributed under the terms of the Creative Commons Attribution 4.0 International (CC BY 4.0) License. 


\section{INTRODUCTION}

The brown meagre, Sciaena umbra Linnaeus, 1758, is one of the five species of the Sciaenidae family present in the Mediterranean Sea. Its distribution range extends also to the eastern Atlantic (from the English Channel to Senegal, including the Canary Island), the Black Sea, the Sea of Marmara, and the Sea of Azov (Artüz 2006, Chao 2015). S. umbra is a sedentary and gregarious species living in shelters on hard bottoms or hidden within Posidonia and Zostera beds (Harmelin 1991, Keskin 2007).

In the northern Mediterranean Sea, S. umbra stocks are considerably reduced due to factors such as their life history traits and behavioural characteristics, habitat degradation, and small-scale professional and recreational fishing pressures (Harmelin 1991). On the northwestern coasts of the Mediterranean Sea, the effects of different reserve protection levels resulted in an increased abundance and biomass of the species, suggesting the negative impact of fishing activities in the area and especially of spearfishing catches (Harmelin-Vivien et al. 2015). As a vulnerable species, the brown meagre is therefore a good indicator of the efficiency of the fishing limitation measures (Harmelin and Ruitton 2007). On the French Mediterranean coasts, a temporary level of partial protection and a ban on all types of recreational fishing has been adopted since 2014 for the recovery of $S$. umbra populations (Harmelin-Vivien et al. 2015).

In the southwestern Mediterranean Sea, the Sciaenidae family is mainly exploited by the small-scale artisanal fisheries on the Tunisian coasts and is recorded in the local fisheries statistics (in 2012, total production was 54 t) (Anonymous 2013). Most of the production came from the southern region of the Gulf of Gabes (59\% of total production), probably in relation to the tropical affinities of this region (Chakroun et al. 1982) and the intensive exploitation of benthic stocks due to active trawling in the Gulf of Gabes (Jabeur et al. 2000).

The age determination and growth rate are determinant for the estimation and explanation of the stock fluctuations and for application of management strategies. For the brown meagre, age and growth have already been studied in Maltese waters (Ragonese et al. 2004), in the Sea of Marmara (Artüz 2006) and in the Adriatic Sea (La Mesa et al. 2008) by the reading of thin otolith sections. Polished otoliths were used in the Black Sea (Engin and Seyhan 2009). In the Gulf of Tunis, age was determined from burnt broken otoliths (Chauvet 1991) and from the scales (Chakroun-Marzouk and Ktari 2003).

The aim of the present study was to update the data relative to age and growth parameters of the brown meagre of the Gulf of Tunis by using thin cross-sections. Further, length-length (fish and otolith radii) and length-weight relationships, as well as mortalities (natural, $M$, and total, $Z$ ), were studied and the respective coefficients were estimated. Finally, an idea of the status of the investigated stock was derived by comparing the current exploitation ratio $(\mathrm{E}=\mathrm{F} / \mathrm{Z})$ with the values conventionally related to a full exploitation. This pa- rameter is indispensable for a rational management of fisheries, which is the only guarantee for a sustainable and responsible exploitation of a fishery resource.

\section{MATERIALS AND METHODS}

\section{Study area, fish sampling and collection of hard structure}

The study was performed in the Gulf of Tunis (central Mediterranean Sea, $\left.37^{\circ} \mathrm{N} 10^{\circ} 30^{\prime} \mathrm{E}\right)$. The brown meagre is caught by commercial fishing boats using artisanal fishing gears (mostly gillnets and trammel nets) and trawl, at depths ranging from 20 to $100 \mathrm{~m}$, according to information provided by experienced fishermen who know the fishing area well. A total of 276 individuals were randomly collected on a monthly basis from October 2008 to September 2011. For each fish, the total length (TL) was measured to the nearest millimetre and the total weight (TW) to the nearest gram. The sex (male, female or undetermined) was determined by macroscopic observation of the gonads. Sagittal otoliths were removed, cleaned and stored dry in labelled envelopes for later treatment and examination.

\section{Sex-ratio and length-weight relationship}

The sex-ratio (males:females) for the entire sample was estimated. A chi-square test was used to detect differences in the sex-ratio of the sampled fish. The Mann-Whitney U test was applied to test the differences between sexes according to the TL $(\mathrm{cm})$ and TW $(\mathrm{g})$ (Zar 1999).

The relation between length and weight was described by the power function $\mathrm{TW}=\mathrm{aTL} \mathrm{T}^{\mathrm{b}}$. The regression parameters $\mathrm{a}, \mathrm{b}$ and the coefficient of determination $\left(r^{2}\right)$ were estimated for the whole population and for each sex by least square linear regression, after log transformation of both variables. According to Ricker (1973), the slope of the regression was corrected to follow a geometric mean regression. A Student t-test was used to appreciate the hypothesis of isometric relationship, whereas analyses of covariance (ANCOVA) were used to detect any significant differences in the linear relationships between sexes (Zar 1999).

\section{Otolith preparation and interpretation}

Before estimating the age, two preliminary steps were applied to choose the calcified structure used and to validate the periodicity of observed growth increments. Comparing the results between the otoliths and the scales, in old fishes age is often underestimated or impossible to estimate when studied by scalimetry. Therefore, sagittal otoliths are the most common and widely used calcified structure. They appear to be highly suitable for age estimation as they are metabolically inert, so any material deposited remains unaltered and cannot be resorbed (Campana and Neilson 1985). Furthermore, some otolith preparation techniques that enhance the visibility of annuli are available, and their applicability depends on the specific characteristics of fish otoliths (Arneri et al. 1998). 
A

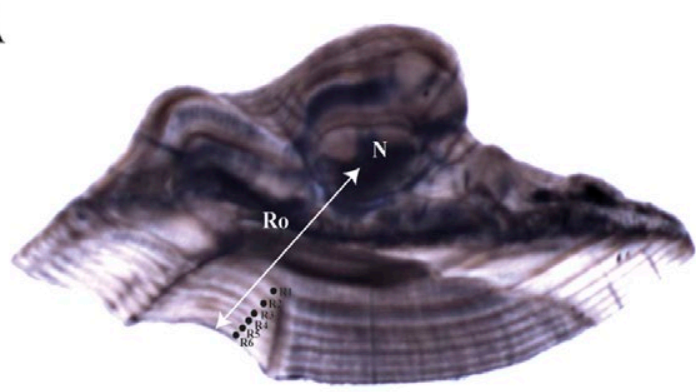

B

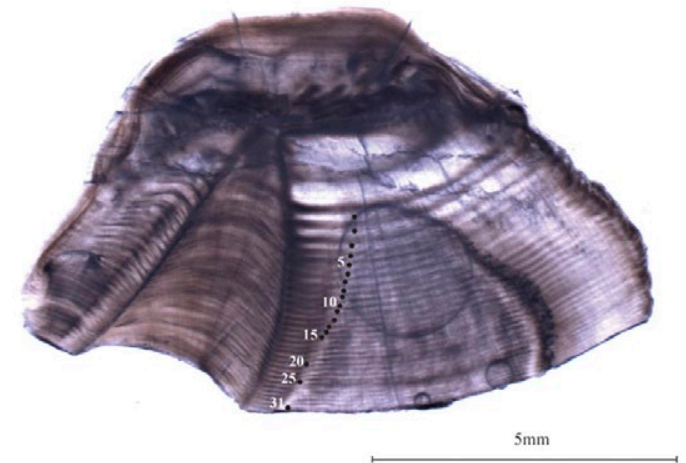

Fig. 1. - Example of otolith cross-sections of Sciaena umbra in the Gulf of Tunis. Individual of 6 years old $(\mathrm{TL}=36.8 \mathrm{~cm}$, male) (A) and 31 years old $(\mathrm{TL}=49.2 \mathrm{~cm}$, female) $(\mathrm{B})$.

Otoliths of S. umbra, like those of most Sciaenids species, are too thick to allow direct reading of the growth marks, so thin cross-sections through the core (nucleus) of the otoliths were used. The preparation method used to section into thin slices was described in Mahé et al. (2009). Otoliths were embedded in translucent polyester resin and two thin cross-sections $(0.45$ $\mathrm{mm}$ thick) were made using a high saw. These sections were then viewed under transmitted light against a white background, using a binocular microscope linked to a video camera connected to a computer. Paraffin oil was used to improve the visualization of growth increments. Each sample was then analysed using TNPC software (numeric treatment of calcified pieces, www. tnpc.fr).

The association of one opaque zone and one translucent zone was considered an annulus. The path of the growth marks was counted from the nucleus towards the tip of the inner face next to the sulcus (Fig. 1A). Measurements were taken from the otolith core to each opaque zone $\left(\mathrm{R}_{\mathrm{n}}\right)$ and to the proximal margin of the otolith $\left(\mathrm{R}_{\mathrm{o}}\right)$ to the nearest $0.01 \mathrm{~mm}$.

The periodicity of opaque zone formation was validated by the marginal increment analysis (Jearld 1983). The marginal increment ratio (MIR, $0.01 \mathrm{~mm}$ ) of fish with more than one opaque zone was calculated by the equation MIR $=R_{0}-R_{n} / R_{n}-R_{n-1}$, where $R_{n}$ and $R_{n-1}$ are the radii of the ultimate and penultimate annuli, respectively. The Kruskal-Wallis test was used to test the homogeneity of MIR among months followed by a Student-Newman-Keuls (SNK) non-parametric test after null hypothesis rejection. Correlation between MIR and temperature was tested using the Spearman rank correlation coefficient $\left(r_{s}\right)$ (Zar 1999). The mean sea water temperature data were supplied by the National Institute of Meteorology of Tunisia (www.meteo.tn). According to the study on the reproductive characteristics of S. umbra in the Gulf of Tunis (Chakroun-Marzouk and Ktari 2003), the peak of the reproductive season is between May and June, so 1 May was considered the birth date of the fish.

\section{Age precision evaluation}

To assess ageing precision, the growth increment was counted independently by two readers without prior knowledge of fish length or sex. The variability of the within-reader age estimates was calculated with the absolute percent error (APE) (Beamish and Fournier 1981) with the equation

$$
\operatorname{APE}_{j}(\%)=100 \frac{1}{R} \sum_{i=1}^{R} \frac{|X i j+X j|}{X j},
$$

where $\mathrm{R}$ is the number of times each fish is aged, $\mathrm{Xij}$ the $i($ th) ageing of the $j($ th) fish and $X$ the mean age calculated for the $j($ th) fish. Only interpretations with an agreement between two readings were used in the successive elaborations.

\section{Growth curve evaluation}

The von Bertalanffy growth function is the most commonly used to describe fish growth. It was fitted to the observed length-at-age data as follow:

$$
T L_{t}=T L_{\infty}\left(1-e^{-k\left(t-t_{0}\right)}\right)
$$

where $\mathrm{TL}_{\mathrm{t}}$ is the total length $(\mathrm{cm})$ at age $t, \mathrm{TL}_{\infty}$ is the asymptotic total length $(\mathrm{cm}), \mathrm{k}$ is the growth curvature $\left(\right.$ years $\left.^{-1}\right), t$ is the age (years) and $t_{0}$ is the theoretical age at which length is zero. These parameters were estimated using Fishparm, a computer program based on a nonlinear model with an algorithm for least-square estimation (Saila et al. 1988).

Separate analyses were done for males and females. The growth curves were compared between sexes using the Hotteling test (Zar 1999). A comparison with other areas was performed producing a synoptic table and an auximetric grid of Pauly et al. (1996), in order to judge the coherence among present and other data.

\section{Mortality and exploitation rates}

Catch curves were constructed by plotting the log of the number of fishes caught against their age class. Only age classes fully recruited to the sampling gear (i.e. the age classes in the descending limb of the catch curve) were used to estimate total mortality (Z). Z was estimated by the slope of the linear regression through the descending right limb of the catch curve (Pauly 1983). The instantaneous rate of natural mortality (M) was estimated by the updated empirical method of Hoenig (1983), $M=4.899 \mathrm{t}_{\max }-0.916$, where $\mathrm{t}_{\max }$ is the maximum age (Then et al. 2015). Then, the instantaneous rate of fishing mortality (F) was obtained from 


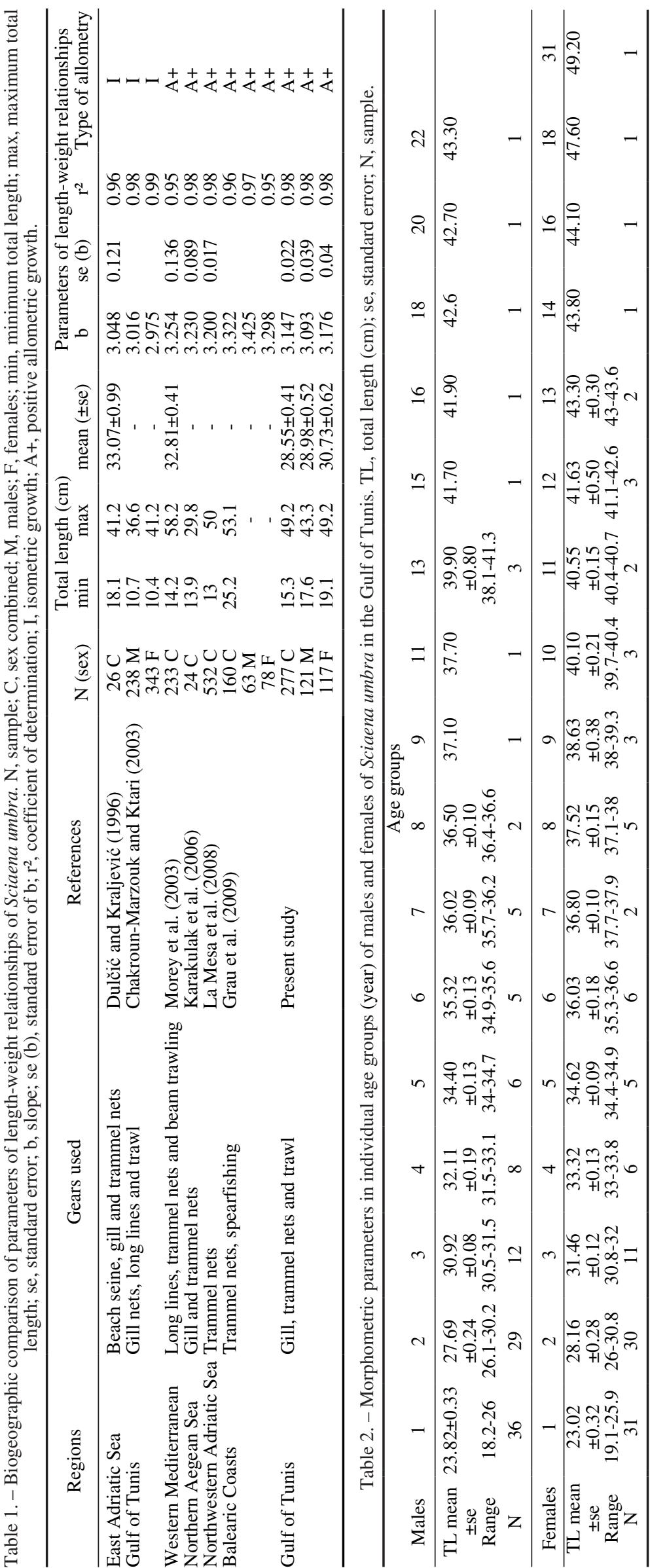

the difference between $\mathrm{Z}$ and $\mathrm{M}$. The exploitation ratio $\mathrm{E}$ was estimated by dividing F by Z (Gulland 1971).

\section{RESULTS}

\section{Sample characteristics, sex-ratio and length-weight relationship}

A total of two hundreds and 76 specimens composed of 121 males, 117 females and 38 specimens with undetermined sex were sampled. The sex-ratio of 1: 0.97 was not significantly different from the $1: 1$ ratio $\left(\chi^{2}=0.7, n=238\right)$.

Males ranged in size from 17.6 to 43.3 $\mathrm{cm}$ and females from 19.1 to $49.2 \mathrm{~cm}$. The mean TL of males $(\mathrm{TL}=28.98 \pm 0.52$ $\mathrm{cm})$ was not significantly different from that of females $(\mathrm{TL}=30.73 \pm 0.62 \mathrm{~cm})$ (Mann-Whitney U test, $\mathrm{n}=238, \mathrm{p}=0.06$ ). Fish of undetermined sex were ranged between 15.3 and $26.3 \mathrm{~cm}(\mathrm{TL}=20.04 \pm 0.50$ cm) (Fig. 2). The total weight of fish was between 67 and $1063 \mathrm{~g}(\mathrm{TW}=335.12 \pm 19.28$ g) for males and between 84 and $1565 \mathrm{~g}$ $(\mathrm{TW}=424.01 \pm 27.73 \mathrm{~g})$ for females. The mean TW was significantly different between the two sexes (Mann-Whitney U test, $\mathrm{n}=238, \mathrm{p}=0.04)$. Total weight of fish with undetermined sex varied between 43 and $239 \mathrm{~g}(\mathrm{TW}=99.83 \pm 8.29 \mathrm{~g})$.

The parameters of the length-weight linear regressions are provided for each sex and all individuals in Table 1. Our data suggested that $S$. umbra showed positive allometric growth. The sex effect was not significant on the length-weight relationships (ANCOVA, $n=238, p>0.05$ ).

\section{Age precision}

Growth increments were counted on otolith cross-sections (Fig. 1A). Among the total sections examined $(n=276), 252$ $(91.3 \%)$ yielded useful age estimates and 24 were discarded as they showed disagreement between the two readings. The value of APE (2.79\%) demonstrated the very good reproducibility between readings, the reliability and the high precision of sectioned otolith for ageing the species.

The marginal increment analysis showed considerable individual variation (Fig. 3) but with a consistent pattern of higher values from August to February and lower values from March to June, the months corresponding to the mark formation period (Kruskall-Wallis test, $\mathrm{p}=0.009$; SNK, $\mathrm{p}=0.001)$. The monthly trend in marginal increment analysis showed that only one mark is deposited per year. Significant cor- 


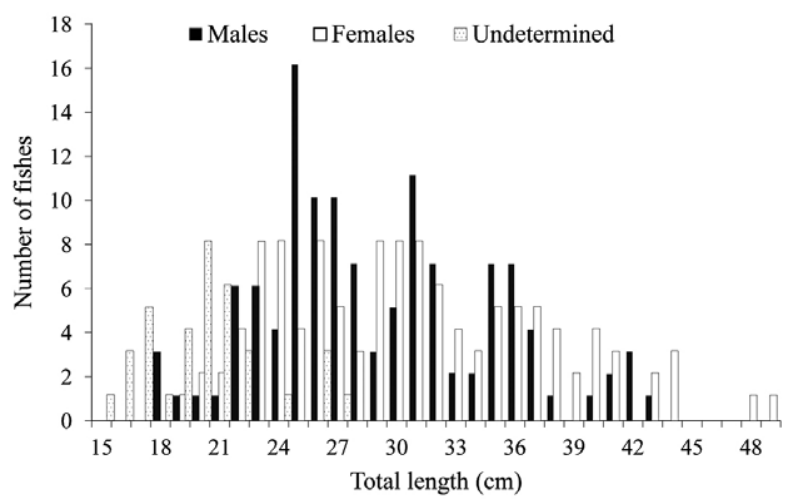

Fig. 2. - Frequency distribution of total length for males, females and individuals with undetermined sex of Sciaena umbra in the Gulf of Tunis.

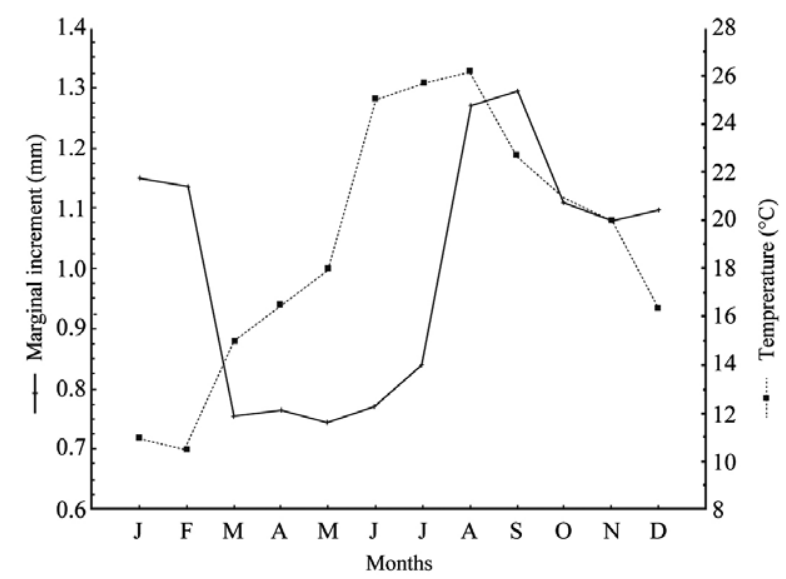

Fig. 3. - Monthly evolution of average marginal increment of Sciaena umbra in the Gulf of Tunis and the associated sea surface mean temperature (spawning period: May, June and July).

relation was found between mean marginal increment values and sea surface temperature $\left(\mathrm{r}_{\mathrm{s}}=0.12, \mathrm{p}<0.05\right)$.

\section{Age and growth}

The relationships between TL and otolith radius (Ro) were calculated for males and females. Fish length and the radius of the calcified structure was closely

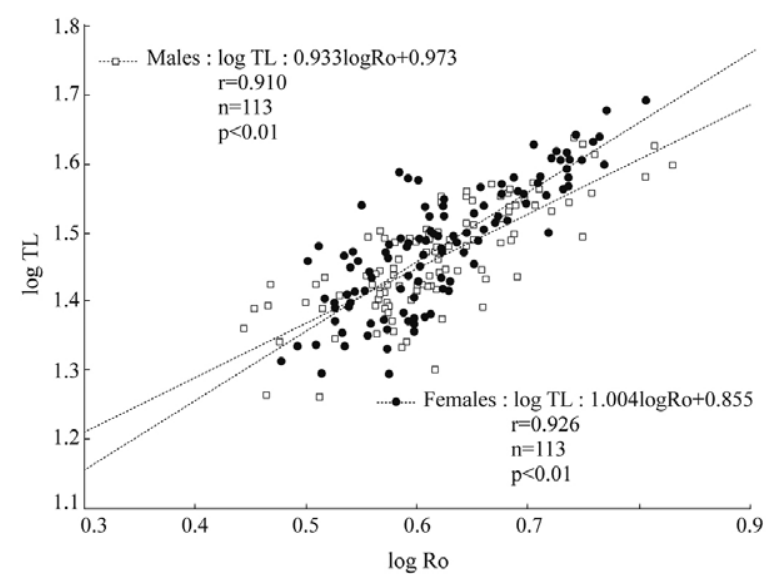

Fig. 4. - Relation between otolith radius (Ro) and total length (TL) of Sciaena umbra in the Gulf of Tunis.

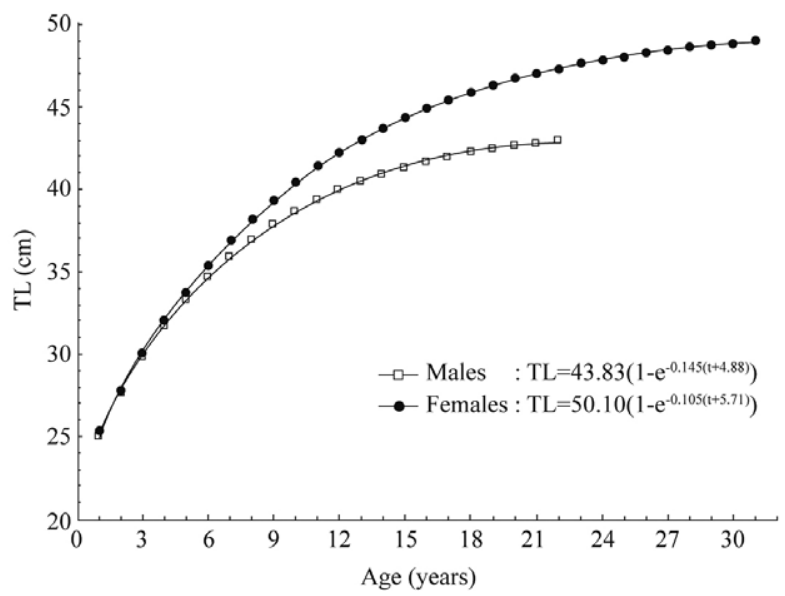

Fig. 5. - von Bertalanffy growth curves for males and females of Sciaena umbra in the Gulf of Tunis.

correlated ( $p=0.00$, Fig. 4$)$. The analysis of covariance showed a significant difference in the length-radius relationship between the two sexes (ANCOVA, $\mathrm{p}<0.05)$.

The observed age of fish ranged from 1 to 31 years (Fig. 1B). Females reached a higher maximum age (31 years) than males (22 years). No significant differences in mean ages between males $(3.74 \pm 0.39$ years) and females $(4.27 \pm 0.43$ years) were observed (Mann-Whitney $\mathrm{U}$ test, $\mathrm{n}=226, \mathrm{p}=0.34)$. Most of the fish, accounting for $69 \%$ of the total sample, were between 1 and 3 years old (Table 2). Fish older than 9 years old were poorly represented in the sample. More than $50 \%$ of the maximum length was achieved by the first year.

The growth curves of age-at-observed length data were well described through von Bertalanffy fits (Fig. 5). Significant differences were found between the von Bertalanffy growth curves of both sexes (Hotelling's $\mathrm{T}^{2}$ test=10.07, $\mathrm{p}<0.05$ ).

The von Bertalanffy relationships between age and length, derived from the assumed annual periodicity of the growth increments, were described by the growth parameters: $\mathrm{TL}_{\infty}=43.83 \mathrm{~cm}, \mathrm{k}=0.145$ year $^{-1}, \mathrm{t}_{0}=-4.88$ years for males and $\mathrm{TL}_{\infty}=50.10 \mathrm{~cm}, \mathrm{k}=0.105$ year $^{-1}$, $\mathrm{t}_{0}=-5.71$ years for females.

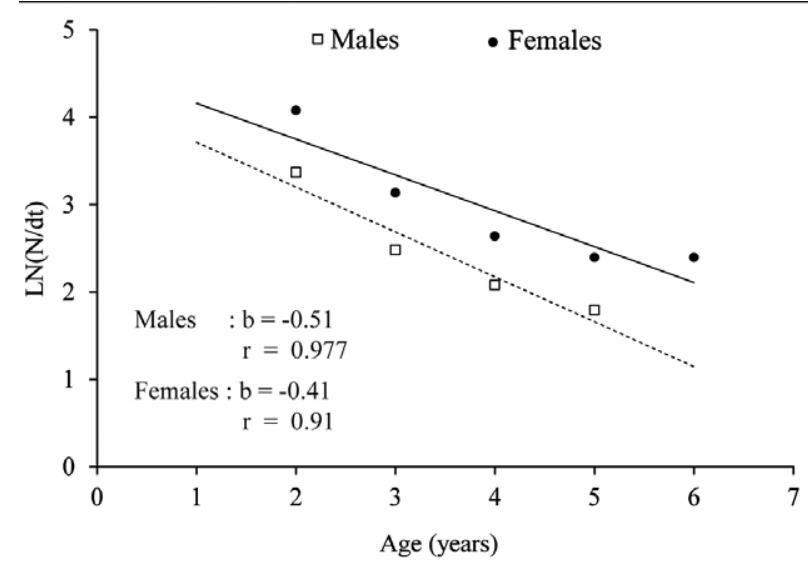

Fig. 6 - Length catch curves for males and females of Sciaena umbra in the Gulf of Tunis. 


\section{Mortality and exploitation rate estimates}

Total mortality, corresponding to the slope of the descending limb of the catch curves, was $Z=0.51$ year $^{-1}$ for males and $Z=0.41$ year $^{-1}$ for females (Fig. 6). Values of natural mortality were $M=0.29$ year $^{-1}$ for males and $\mathrm{M}=0.22$ year $^{-1}$ for females. Calculation of fishing mortality gave $\mathrm{F}=0.22$ year $^{-1}$ for males and $\mathrm{F}=0.19$ year ${ }^{-1}$ for females. With the values of $\mathrm{M}$ and $\mathrm{F}$ known, the exploitation ratios were computed as $\mathrm{E}=0.43$ for males and $\mathrm{E}=0.46$ for females.

\section{DISCUSSION}

\section{Length-weight relationship}

This study showed no significant difference between the length-weight relationships of males and females of $S$. umbra. This result corroborates the study realized in the northwestern Adriatic Sea (La Mesa et al. 2008). The length-weight relationship parameters obtained from different areas are given in Table 1. The slope values (b) of the length-weight relationships for both sexes ( $b=3.09$ for males, $b=3.18$ for females) and for the entire sample $(b=3.15)$ showed a positive allometric growth. These results are different from those found by Chakroun-Marzouk and Ktari (2003) in the same area and by Dulčić and Kraljević (1996) in the east Adriatic Sea, where the growth was isometric. Our results corroborated those obtained in the western Mediterranean Sea, around the Balearic Islands and the eastern coast of the Iberian Peninsula (Morey et al. 2003, Grau et al. 2009). In the northern Aegean Sea (Karakulak et al. 2006) and the northwestern Adriatic Sea (La Mesa et al. 2008), a positive allometric growth was also reported. The fluctuating pattern of the lengthweight relationship can be assigned to factors such as food availability and feeding rates (Bagenal and Tesch 1978), the temporal effect related to the spawning season (Mahé et al. 2017), composition in size of the individuals sampled and the period of sampling (Moutopoulos and Stergiou 2002). Table 1 shows differences in the size interval of captured fishes, samples showing a positive allometry being composed of larger individuals than those with isometric growth. For this reason, Petrakis and Stergiou (1995) suggested that the use of the length-weight relationship and its comparison must be limited to the interval of size used to evaluate linear regression parameters.

\section{Age and growth}

The large size and thickness of the otoliths in Sciaenids species do not allow a direct reading on the surface of the whole otolith under reflected or transmitted light. The dense calcium carbonate deposition reduces light transmission, making it almost impossible to distinguish hyaline and opaque zones (Arneri et al. 1998). Consequently, different otolith preparation techniques (burnt, polished and sectioned) have been tried. Cross-sections have proved to be a very effective method for determining the age of Mediterranean brown meagre (Arneri et al. 1998). The significant correlation observed between the TL and the radius of the otolith cross-section indicated that this structure is useful for estimating age and for reconstructing the past growth history of $S$. umbra.

The low values of APE found in this study, like those determined by La Mesa et al. (2008) in the Adriatic Sea, indicate a high precision between readers and suggest the good precision of the otolith cross-section method for ageing this species.

Marginal increment analysis confirmed the deposition periodicity of growth increments, showing an annual pattern. It also proved that the opaque zone was deposited between March and June. This period is identical to that observed for the formation of the annulus on the scales of the brown meagre in the same area (Chakroun-Marzouk and Ktari 2003). In the Adriatic Sea, La Mesa et al. (2008) noted the thinnest marginal increment value in July. The formation of alternating translucent and opaque zones might be related to a complex control by environmental and endogenous factors (Beckman and Wilson 1995). Indeed, physiological changes are produced mainly by cyclic variations of temperature, photoperiodism and food supply (Pannella 1980). The temperature mean showed the same trend as the marginal increment analysis, with a small time lag (1 or 2 months). This pattern is linked to temporal fluctuations in metabolism and water temperature, where seasonal temperature variations exceed $3^{\circ} \mathrm{C}$ to $4^{\circ} \mathrm{C}$ (Høie et al. 2008, Neat et al. 2008). The patterns of opaque and translucent zone formation have been linked to a seasonal change in otolith daily increments widths (Beckman and Wilson 1995) themselves in relation to variations in the rhythm of the metabolism of calcium (aragonite) and organic material (otolin) (Morales-Nin 1987).

The examination of otolith cross-sections showed that the maximum age observed in the Gulf of Tunis was 31 years for a female of $49.2 \mathrm{~cm}$. A very similar result of the same age was found for a female of 49.7 $\mathrm{cm}$, poached in the marine reserve of Scandola, protected since 2014 (Morat et al. 2017). It appears that the brown meagre of the Gulf of Tunis has the longest

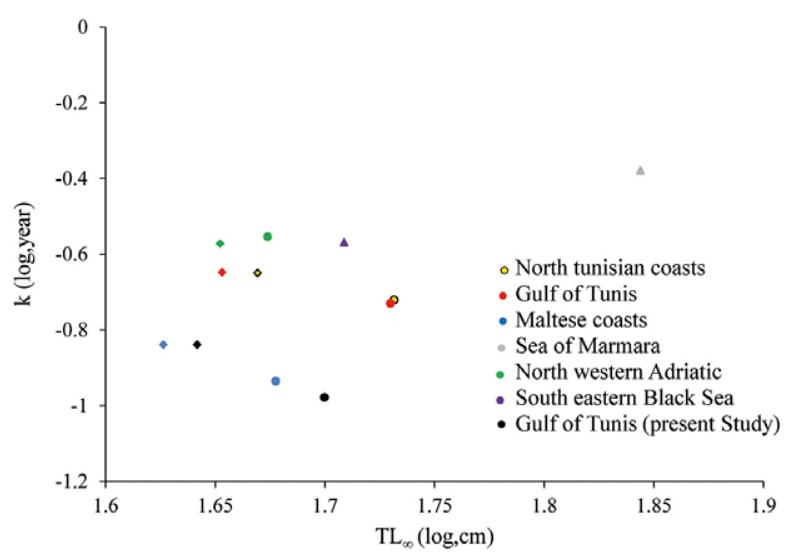

Fig. 7. - Auximetric grid showing the relationship performance of Sciaena umbra from different areas. The different studies are indicated with different colour. Growth performance of males are represented by diamonds, females by circles and combined sex by triangles. 


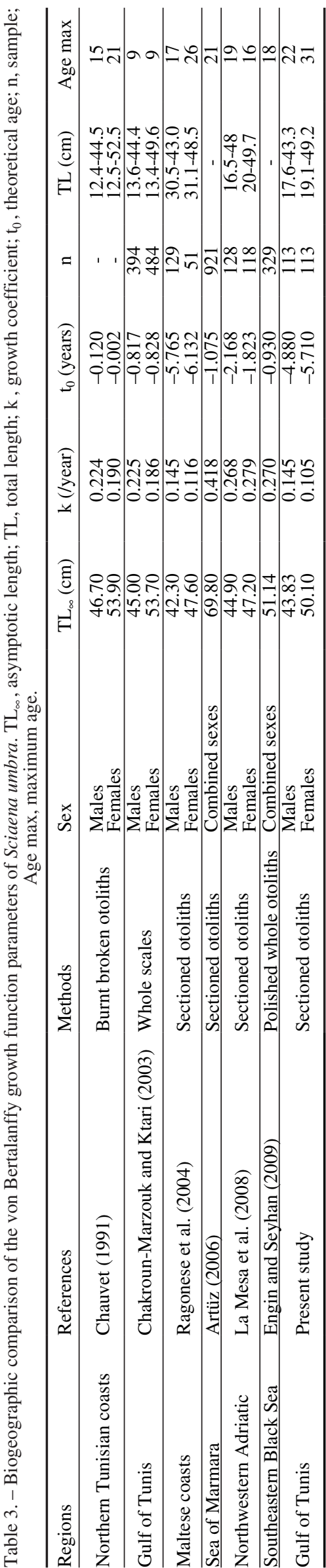

life span reported until now in a natural environment. Indeed, in Maltese waters, the Sea of Marmara, the northwestern Adriatic and the southeastern Black Sea, the oldest individual was 26 years old (Table 3 ). In a previous study of the growth of $S$. umbra in the Gulf of Tunis, Chauvet (1991) used burnt broken whole otoliths and determined a maximum age of 21 years. Using scales, the maximum readable age was only 9 years (Chakroun-Marzouk and Ktari 2003). Further differences in observed growth pattern may therefore be due, in part, to the calcified structure used or its preparation method.

In the growth parameters of the von Bertalanffy model obtained, the theoretical maximal length value is close to the observed largest size. $S$. umbra grows quickly during the first two years, attaining approximately 55\% of its maximum length, but the annual growth rate drops rapidly thereafter. A similar result was found previously in the Gulf of Tunis, where males and females attained 50\% of their maximum length during the first two years of life (Chakroun-Marzouk and Ktari 2003). In the Adriatic Sea, La Mesa et al. (2008) also reported a rapid increase in size during the first two to three years of life. Juveniles used all the energy available for somatic growth. High negative values of $t_{0}$ were reported in Maltese waters (Ragonese et al. 2004) and in the Adriatic Sea (La Mesa et al. 2008), probably reflecting the fast growth rate of juveniles.

The comparison of the growth parameter estimates of $S$. umbra from different geographical areas (Fig. 7, Table 3) shows substantial discrepancies. In the Gulf of Tunis, females were found to grow larger than males. The sexual dimorphism was reported too in the same area (Chauvet 1991, ChakrounMarzouk and Ktari 2003), in Maltese waters (Ragonese et al. 2004) and in the Adriatic Sea (La Mesa et al. 2008). The estimates of the asymptotic length $\mathrm{TL}_{\infty}$ were lower than those found previously in the same area for both sexes (Chauvet 1991, Chakroun-Marzouk and Ktari 2003) but slightly higher in Maltese waters (Ragonese et al. 2004) (Fig. 7). In all the growth studies on $S$. umbra, the values of the Brody growth coefficient k confirm a slow attainment of maximal size, which is rather characteristic of long life cycle species. The high growth performance of S. umbra reported by Artüz (2006) in the Sea of Marmara was the result of the high Brody growth coefficient recorded in this locality, coupled to the high asymptotic length. This result seems to reflect, the growth of recruits and juveniles, although the length range of the studied sample is not reported.

These variations in growth performance between different regions are probably the result of the following factors:

(1) Variations in environmental conditions (such as temperature and food availability) among sampled areas.

(2) Different size distributions (probably caused by different types of sampling gear). In fact, growth model estimates are greatly affected by the lack of very young or old individuals and the unequal abundance of size classes (Mouine-Oueslati et al. 2015).

(3) Distribution difference between sexes when there was sexual dimorphism as for this species.

(4) Mortality, which may affect the variability of the maximum length and has a relatively large and consistent impact on the size of structure of communities (Blanchard et al. 2005).

(5) A combination of the above factors.

\section{Exploitation rate and management measures}

Gulland (1971) suggested that a fish stock is optimally exploited when fishing mortality is equal to natural mortality. More recently, Pauly (1987) proposed a lower threshold value, $\mathrm{E}=0.4$. Basing his suggestion on research by Beddington and Cooke (1983), Pauly (1987) proposed a lower optimum fishing mortality, $\mathrm{F}_{\mathrm{opt}}=0.4 \mathrm{M}$. $\left(\mathrm{F}>\mathrm{F}_{\mathrm{opt}}=0.12\right.$ for males and $\mathrm{F}>\mathrm{F}_{\mathrm{opt}}=0.09$ for females). Estimates for females are considered more relevant for population modelling, because aspects of female population dynamics, including age-specific and total life-time fecundity and mortality, determine the potential increase in population numbers (Bishop et al. 2006). In the Gulf of 
Tunis, during the study period, the stock of $S$. umbra was slightly overexploited $\left(\mathrm{E}>0.4\right.$ and $\left.\mathrm{F}>\mathrm{F}_{\text {opt }}\right)$. On the Tunisian coasts, females reached ages of 31 years, which is the maximum age recorded in the Mediterranean Sea. The studied life history parameters of the population of the brown meagre of the Gulf of Tunis suggest that the species is long-lived, is slow growing and slow-maturing, and has a low natural mortality. Because of all these previous characteristic, S. umbra is a species vulnerable to inconsiderate fishing pressure. In the Gulf of Tunis, the brown meagre seems preserved from excessive fishing and particularly from spearfishing. Recent recreative fishing activity had a negative impact on its stocks on the northwestern coasts of the Mediterranean Sea, but it this is a very limited activity on the Tunisian coasts.

The results obtained from the current study provide an actualization of practical biologically related parameters for stock assessment and management of the brown meagre of the Gulf of Tunis. Regular follow-up of life history traits of this species are necessary for its optimal management on the Tunisian coasts.

\section{REFERENCES}

Anonymous. 2013. Annuaires statistiques des produits de la pêche en Tunisie de 2001 à 2012. Direction générale de la pêche et de l'aquaculture du ministère de l'agriculture à Tunis

Arneri E., Colella S., Giannetti G. 1998. A method for the age determination of two Mediterranean Sciaenids Sciaena umbra (Linnaeus, 1758) and Umbrina cirrosa (Linnaeus, 1758). Rapp. Comm. int. Mer Médit. 35: 366-367.

Artüz M.L. 2006. Abundance and growth observations of Sciaena umbra Linnaeus, 1758 in Sea of Marmara. Hydrobiologica 1a: 124-128.

Bagenal T.B., Tesch F.W. 1978. Age and growth. In: Bagenal T. (eds), Methods for Assessment of Fish Production in Fresh Waters. Blackwell Scientific Publications, Oxford, pp. 101-136.

Beamish R.J., Fournier D.A. 1981. A method for comparing the precision of a set of age determination. Can. J. Fish. Aquat. Sci. 38: 982-983. https://doi.org/10.1139//81-132

Beckman D.W., Wilson C.A. 1995. Seasonal timing of opaque zone formation in fish otoliths. In: Secor D.H., Dean J.M., Campana S.E. (eds), Recent Developments in Fish Otoliths Research Vol. 19. The Bella W Braruch Library in Marine Science, South Carolina, pp. 27-43

Beddington J.R., Cooke J.G. 1983. On the potential yield of fish stocks. FAO Fisheries Technical Paper, 242 pp.

Bishop S.D.H., Francis M.P., Duffy C. et al. 2006. Age, growth, maturity longevity and natural mortality of the shortfin shark (Isurus oxyrinchus) in New Zeland waters. Mar. Freshwater. Res. 57: 143-154. https://doi.org/10.1071/MF05077

Blanchard J.L., Dulvy N.K., Jennings S. et al. 2005. Do climate and fishing influence size-based indicators of Celtic Sea fish community structure? ICES J. Mar. Sci. 62: 405-411. https://doi.org/10.1016/j.icesjms.2005.01.006

Campana S.E., Nielson J.D. 1985. Microstructure of fish otoliths. Can. J. Fish. Aquat. Sci. 42: 1014-1032. https://doi.org/10.1139/f85-127

Chakroun N., Ktari M.H., Kammoun M.N. 1982. Production des Sciaenidae (Poissons, Téléostéens) des côtes tunisiennes. Bull. Inst. Nat. Scient. Tech. Océanog. Pêche Salammbô 9: 121-126.

Chakroun-Marzouk N., Ktari M.H. 2003. Le Corb des côtes tunisiennes, Sciaena umbra (Sciaenidae): Cycle sexuel, âge et croissance. Cybium 27: 211-225.

Chao L.N. 2015. Sciaena umbra. The IUCN Red List of Threatened Species 2015

Chauvet C. 1991. Le Corb ou Brown meagre (Sciaena umbra Linnaeus, 1758): Quelques éléments de sa biologie. In: Boudouresque C.F., Avon M., Gravez V. (eds), Les espèces marines à protéger en Méditerranée. GIS Posidonie publication, France, pp. 229-235.

Dulčić J., Kraljević M. 1996. Weight-length relationships for 40 fish species in the eastern Adriatic (Croatian waters). Fish. Res. 28: 243-251. https://doi.org/10.1016/0165-7836(96)00513-9

Engin S., Seyhan K. 2009. Age, growth, sexual maturity and food composition of Sciaena umbra in the south-eastern Black Sea, Turkey. J. App. Ichthyol. 25: 96-99. https://doi.org/10.1111/j.1439-0426.2008.01173x

Grau A., Linde M., Grau A.M. 2009. Reproductive biology of the vulnerable species Sciaena umbra Linnaeus, 1758 (Pisces: Sciaenidae). Sci. Mar. 73: 67-81.

https://doi.org/10.3989/scimar.2009.73n1067

Gulland J.A. 1971. The fish resources of the oceans. Fishing News Books Ltd. West by fleet survey, England, $255 \mathrm{pp}$.

Harmelin J.G. 1991. Statut du Corb (Sciaena umbra) en Méditerranée. In: Boudouresque C.F., Avon M., Gravez V. (eds), Les espèces marines à protéger en Méditerranée. GIS Posidonie publications, France, pp. 219-227.

Harmelin J.G., Rouitton S. 2007. La population du corb (Sciaena umbra: Pisces) du parc national de Port-Cros (France), état en 2005 et évolution depuis 1999: un indicateur halieutique et biogéographique pertinent. Sci. Rep. Port-Cros natl. Park, Fr. 22: 49-65.

Harmelin-Vivien M., Cottalorda J.M., Dominici J.M. et al. 2015. Effects of reserve protection level on the vulnerable fish species Sciaena umbra and implications for fishing management and policy. Global Ecol. Conserv. 3: 279-287. https://doi.org/10.1016/j.gecco.2014.12.005

Hoenig J. 1983. Empirical use of longevity data to estimate mortality rates. Fish. Bull. 82: 898-903.

Høie H., Folkvord A., Mesogaord H. et al. 2008. Restricted fish feeding reduces cod otolith opacity. J. Appl. Ichthyol. 24: 138-143. https://doi.org/10.1111/j.1439-0426.2007.01014.x

Jabeur C., Gobert B., Missaoui H. 2000. Typologie de la flottille de pêche dans le golfe de Gabès (Tunisie). Aquat. Living. Resour. 13: 421-428. https://doi.org/10.1016/S0990-7440(00)01069-X

Jearld A. 1983. Age determination. In: Nielsen L.A., Johnson D.L. (eds), Fisheries Techniques. American Fisheries Society, Bethesda, pp. 301-324.

Karakulak F.S., Erk H., Bilgin B. 2006. Length-weight relationships for 47 coastal fish species from the northern Aegean Sea, Turkey. J. App. Ichthyol. 22: 274-278. https://doi.org/10.1111/j.1439-0426.2006.00736.x

Keskin C. 2007. Temporal Variation of Fish Assemblages in Different Shallow-water Habitats in Erdek Bay, Marmara Sea, Turkey. J. Black Sea/Medit. Environ. 13: 215-234.

La Mesa M., Colella S., Giannetti G. et al. 2008. Age and growth of brown meagre Sciaena umbra (Sciaenidae) in the Adriatic Sea. Aquat. Living Resour. 21: 153-161. https://doi.org/10.1051/alr:2008029

Mahé K., Bellail R., Dufour J.L. et al. 2009. Synthèse française des procédures d'estimation d'âge. IDM/RIC, IFREMER, Brest, France, $78 \mathrm{pp}$.

Mahé K., Bellamy E., Delpech J. et al. 2017. Evidence of a relationship between weight and total length of marine fish in Northeastern Atlantic: Physiological, spatial and temporal variations. J. Mar. Biol. Ass. U.K. 1-9. In press. https://doi.org/10.1017/S0025315416001752

Morales-Nin B. 1987. The influence of environmental factors on microstructure of otoliths of three demersal fish species caught off Namibia. In: Payne A.I.L., Gulland J.A., Brink K.H. (eds), The Benguela and Comparable Ecosystems. S. Afr. J. Mar. Sci. 5: $255-262$ https//doi.org/10.2989/025776187784522207

Morat F., Marshal C., Dominici J.M. et al. 2017. A 31-year-old meagre female poached in the Scandola marine reserve in Corsica, France. Cybium 41: 79-80.

Morey G., Moranta J., Massuti E. et al. 2003. Weight-length relationships of littoral to lower slope fishes from the western Mediterranean. Fish. Res. 62: 89-96. https://doi.org/10.1016/S0165-7836(02)00250-3

Mouine-Oueslati N., Romdhani A., Chater I. et al. 2015. Age and growth of Spondyliosoma cantharus (Sparidae) in the Gulf of Tunis. Sci. Mar. 79: 319-324. https://doi.org/10.3989/scimar.04234.13A

Moutopoulos D.K., Stergiou K.I. 2002. Length-weight and lengthlength relationships of fish species from the Aegean Sea 
(Greece). J. App. Ichthyol. 18: 200-203.

https://dx.doi.org/10.1046/j.1439-0426.2002.00281.x

Neat F.C., Wright P., Fryer R.J. 2008. Temperature effects on otolith pattern formation in Atlantic Cod Gadus morhua. J. Fish Biol. 73: 2527-2541.

https://doi.org/10.1111/j.1095-8649.2008.02107.x

Pannella G. 1980. Growth patterns in fish sagittae. In: Rhods D.C., Lutz R.A. (eds), Skeletal growth of aquatic organisms. Plenum press, New York, pp. 519-560.

Pauly D. 1983. Some simple methods for the assessment of tropical fish stock. FAO Fish. Tech. Pap. 234: 1-52. https://doi.org/10.1002/iroh.19840690521

Pauly D. 1987. A review of the ELEFAN system for analysis of length frequency data in fish and invertebrates. In: Pauly D., Morgan G.R. (eds), Length based Methods in Fisheries Research. ICLARM Conf. Proc. 13, Manila, pp. 7-34.

Pauly D., Moreau J., Gayanilo F.Jr. 1996. A new method for comparing the growth performance of fishes, applied to wild and farmed tilapias. In: Pullin R.S.V., Lazard J., Legendre M. et al. (eds), The Third International Symposium on Tilapia in Aquaculture. ICLARM Conf. Proc. 41: 433-441.
Petrakis G., Stergiou K.I. 1995. Weight-length relationships for 33 fish species in Greek waters. Fish. Res. 21: 465-469. https://doi.org/10.1016/0165-7836(94)00294-7

Ragonese S., Gancitano S., Camilleri M. et al. 2004. An integrate analysis of size at age data of Sciaena umbra L. 1758 (Osteichthyes, Sciaenidae) of the central Mediterranean Sea. Biol. Mar. Medit. 11: 612-616.

Ricker W.E. 1973. Linear regressions in fishery research. J. Fish. Res. Board Can. 30: 409-434. https://doi.org/10.1139/f73-072

Saila S.B., Recksiek C.W., Prager M.H. 1988. Basic fishery science programs. A compendium of microcomputer programs and manual of operation. Dev. Aquacult. Fish. Sci. 18: 1-203.

Then A.Y., Hoenig J.M., Hall G.N. et al. 2015. Evaluating predictive performance of empirical estimators of natural mortality rate using information on over 200 fish species. ICES J. Mar. Sci. 72: 82-92 https://doi.org/10.1093/icesjms/fsu136

Zar J.H. 1999. Biostatistical analysis. Prentice-Hall, New Jersey, $66 \mathrm{pp}$. 